\title{
Effect of long-term fertilizer application in maize crop growing on chemical element leaching in Fluvisol
}

\author{
Tsetska Simeonova ${ }^{1 *}$, Dimitranka Stoicheva ${ }^{1}$, Venelina Koleva ${ }^{1}$, Zofia Sokołowska ${ }^{2}$, \\ and Mieczysław Hajnos ${ }^{2}$

\begin{abstract}
${ }^{1}$ Department of Agroecology, Institute of Soil Science, Agrotechnology and Plant Protection "N. Poushkarov",7 Shosse Bankya str., Sofia 1080, Bulgaria

${ }^{2}$ Instiute of Agrophysics, Polish Acadmy of Sciences, Doświadczalna 4, 20-290 Lublin, Poland
\end{abstract}

Received September 29, 2016; accepted april 17, 2017

\begin{abstract}
A b s t r a c t. The study characterized the regime of nutrient leaching under different nitrogen and phosphorus supply of irrigated maize grown as monoculture on Fluvisol for the period 1999-2008 and additionally studied in the years 2009, 2010, and 2011. The aim of the study was to estimate the effect of longterm fertilizer application on the leaching of nutrients from the soil under maize grown as monoculture. The experiment design included four nitrogen fertilizer rates $\left(\mathrm{B}_{1}\right.$-control, $\left.\mathrm{B}_{5}, \mathrm{~B}_{4}, \mathrm{~B}_{3}, \mathrm{~B}_{2}\right)$ calculated to compensate $50,75,100$, and $125 \%$ from the plant $\mathrm{N}$ uptake, respectively. The field plots were equipped with lysimeters (at 50 and $100 \mathrm{~cm}$ depth) for studying the relationship between the applied fertilizer rates and the nutrient concentrations in the lysimetric water. The greatest nitrogen concentration in lysimetric water was observed under variant $\left(\mathrm{B}_{3}-\mathrm{N}_{200} \mathrm{P}_{150}\right)$ throughout the study period and the highest $\mathrm{N}$ losses were registered $\left(36 \mathrm{~kg} \mathrm{ha}^{-1}\right)$ in 2010 under the same treatment $\left(\mathrm{B}_{3}\right)$. A very good correlation was found between the $\mathrm{N}$ rates, calcium, and magnesium losses. Lysimetric water component compensation shows that agricultural activities have only influenced the speed of weathering and had no significant effect on the rates.

$\mathrm{K}$ e y w o r d s: fertilization, field experiment, lysimetric water, nutrients, chemical components
\end{abstract}

\section{INTRODUCTION}

The demand and food production is expected to increase in the next decades worldwide, which will put strong pressure on the environment due to the increasingly massive use of fertilizers. Soil fertility management have an influence not only on the quantity and quality of plant production but also on the agroecosystem. However, from the ecological point of view, the impact of the strength of anthropogenic load with nitrogen fertilizers can be assessed based on the established conditions for migration of chemi-

*Corresponding author e-mail: cecka_simeonova@abv.bg cal elements under one-meter soil layer. Many studies have documented that the chemical composition of lysimetric water depends on the natural conditions - geology and hydrology of the land, soil type and climatic conditions, the form and amount of fertilizer used, and the processes of weathering (Atanassov et al., 1985; Meissner et al., 2010; Stoichev, 1997; Stoichev et al., 1996; Zhao, 2010). It is estimated that the rate of weathering of various minerals is a function of export of dissolved chemical elements draining the soil profile and are determined by the mineral and chemical composition of soil forming rocks (Chadwick and Chorover, 2001; Taylor and Velbel, 1991; Yakubu and Ojanuga, 2013).

Some studies have been made on the climatic factors and changes that have a great impact on pedogenic weathering of minerals (White and Blum, 1995). Therefore (Atanassov, 1977), data on the content and migration of nutrients with infiltration water can provide objective information about the nature and trends in the weathering processes of soil minerals as a result of anthropogenic loading.

The aim of the study was to estimate the effect of long-term fertilizer application on leaching of selected components, including nutrients when maize is grown as monoculture.

\section{MATERIAL AND METHODS}

The field experiment was set up in 1972 at the experimental station of the N. Poushkarov Institute of Soil Science, Agrotechnology and Plant Protection in the village of Tsalpitsa, Southern Bulgaria $\left(24^{\circ} 35^{\prime} \mathrm{E}, 42^{\circ} 14 \mathrm{~N}\right)$. The soil was classified as Alluvial-meadow soil (Koynov,

(C) 2017 Institute of Agrophysics, Polish Academy of Sciences 
T a b l e 1. Characteristics of the alluvial-meadow soil - Eutric Fluvisol

\begin{tabular}{|c|c|c|c|c|c|c|c|c|c|c|}
\hline \multirow{3}{*}{ Horizons } & \multirow{3}{*}{$\begin{array}{c}\text { Depth } \\
(\mathrm{cm})\end{array}$} & \multirow{3}{*}{$\mathrm{pH}_{\mathrm{H}_{2} \mathrm{O}}$} & \multirow[b]{2}{*}{ Humus } & \multirow[b]{2}{*}{ Total N } & \multirow{3}{*}{ C:N } & \multirow{3}{*}{$\begin{array}{c}\mathrm{CaCO}_{3} \\
(\%)\end{array}$} & \multirow{3}{*}{$\begin{array}{c}\text { Sorption } \\
\text { capacity } \\
\left(\text { meq } 100 \mathrm{~g}^{-1}\right)\end{array}$} & \multicolumn{3}{|c|}{ Particle size $(\mathrm{mm})$} \\
\hline & & & & & & & & $2.0-0.02$ & $\begin{array}{l}0.02- \\
0.002\end{array}$ & $<0.002$ \\
\hline & & & \multicolumn{2}{|c|}{$(\%)$} & & & & & $\%$ & \\
\hline $\mathrm{A}_{\text {arable }}$ & $0-35$ & 6.0 & 0.70 & 0.052 & 7.8 & 0.00 & 7.92 & 66.3 & 16.2 & 17.5 \\
\hline $\mathrm{A}_{2}$ & $35-60$ & 6.4 & 0.55 & 0.050 & 6.4 & 0.00 & 18.18 & 43.4 & 14.8 & 41.8 \\
\hline $\mathrm{A}_{3} \mathrm{C}_{1}$ & $60-87$ & 6.5 & 0.42 & 0.042 & 5.8 & 0.00 & 22.77 & 33.5 & 20.6 & 45.9 \\
\hline $\mathrm{C}_{2}$ & $87-118$ & 6.5 & 0.38 & 0.030 & 7.5 & 0.00 & 23.11 & 31.4 & 29.6 & 39.0 \\
\hline
\end{tabular}

According to Stoichev $(1974,1997)$.

1987), which corresponds to Eutric Fluvisol in the FAO classification WRBSR (FAO, 1998). The physico-chemical properties of the soil are presented in Table 1.

The soil has coarse texture, low water holding capacity, and conditions for fast water movement downward the profile. The arable horizon is characterized by slightly acid soil reaction $\mathrm{pH}_{\mathrm{H}_{2} 0}=6.0$, low humus and total nitrogen content, respectively 0.70 and $0.052 \%$, and low cation exchange capacity in the plough soil layer. The agrochemical characteristics of the Alluvial Meadow soil are mineral nitrogen content $-21.25 \mathrm{mg} \mathrm{kg}^{-1}$ and available phosphorus and potassium -7.50 and $10.20 \mathrm{mg} 100 \mathrm{~g}^{-1}$, respectively for the $0-30 \mathrm{~cm}$ layer.

The region belongs to the transition subzone between Moderate and Mediterranean Continental climate zones. According to the classification of the country thermal conditions, the experimental area belongs to temperate hot and dry zone (Levichanska, 1991). The region is characterized with the following mean annual climatic parameters: annual precipitation of 384, 655 and $443 \mathrm{~mm}$ in 2009, 2010, and 2011 , respectively with the average annual air temperature $12.5-12.8^{\circ} \mathrm{C}$.

The long-term field trial was set up with irrigated maize (Zea mays L., FAO group 500 and 700) grown as monoculture. The single-factor experiment included 4 levels of $\mathrm{N}$ fertilization including an unfertilized plot $\left(\mathrm{B}_{1}\right)$. In the optimum treatment $\left(\mathrm{B}_{3}\right)$, the rate was calculated for full compensation of the nitrogen uptake by the crop production. The rates for the other treatments were: 125,75 , and $50 \%, \mathrm{~B}_{2}, \mathrm{~B}_{4}$, and $\mathrm{B}_{5}$, respectively of the amounts of optimum treatment. The scheme of the field experiment and the principle of determination of fertilizer rates are described in more detail by Stoichev (1997). The average rates of fertilization with nitrogen and phosphorus for the two periods 1999-2008 and 2009-2011 were $\mathrm{B}_{1}-\mathrm{N}_{0} \mathrm{P}_{0}, \mathrm{~B}_{2}$ $\mathrm{N}_{250} \mathrm{P}_{187}, \mathrm{~B}_{3}-\mathrm{N}_{200} \mathrm{P}_{150}, \mathrm{~B}_{4}-\mathrm{N}_{150} \mathrm{P}_{112}$, and $\mathrm{B}_{5}-\mathrm{N}_{100} \mathrm{P}_{75} \mathrm{~kg} \mathrm{ha}{ }^{-1}$. Nitrogen fertilizers were applied as ammonium nitrate $-2 / 3$ of the rate was spread before sowing, and $1 / 3$ - in spring.
Phosphorous fertilizer was applied as super phosphate each year before planting. Potassium fertilizer was applied at the beginning of the field trial, but not thereafter. Soil management practices and other agrotechnical inputs were applied according to the standard technology for the crop growing.

Modified Ebermayer-Shilova lysimeters $\left(0.11 \mathrm{~m}^{2}\right)$ (Stoichev, 1974) were installed at $1 \mathrm{~m}$ below the soil surface to collect leachate from the soil profile, under three replications of treatments $\mathrm{B}_{1}, \mathrm{~B}_{5}$, and $\mathrm{B}_{3}$. The contact trays of the lysimeters were cut into the soil profile without disturbing the overlaying soil layers. They were made of PVC and filled with polyethylene grains to ensure good contact between soil and lysimeters and good infiltration. Leachates were collected monthly from the plastic containers $(5.01)$ at the bottom outlet of each lysimeters and analysed for nitrates and other components. The $\mathrm{pH}$ values and chemical composition $\left(\mathrm{NO}_{3}-\mathrm{N}, \mathrm{Na}^{+}, \mathrm{K}^{+}, \mathrm{Ca}^{2+}, \mathrm{Mg}^{2+}\right.$, $\mathrm{HCO}_{3}^{-}, \mathrm{Cl}^{-}, \mathrm{SO}_{4}{ }^{2-}, \mathrm{SiO}_{2}$ ) of lysimetric water and precipitation were determined using the following methods: $\mathrm{pH}$ - potentiometrically (Arinushkina, 1970); nitrogen content, sulphates and Silicate was measured by 'Spectroquant Pharo 100'; potassium and sodium were determined by a flame photometer, calcium and magnesium - by atomic absorption spectrometry - AAS (Page et al., 1982), hydrocarbonate by titration with $0.02 \mathrm{M} \mathrm{H}_{2} \mathrm{SO}_{4}$ to $\mathrm{pH} 4.4$, and chlorine by the Moor method (Arinushkina, 1970).

Lysimetric water analysis was used to assess the effect of agricultural activities on primary material weathering. The approach used to analyse the weathering process involves a charge-based compensation of lysimetric water anions and cations (Garels and Makkensi, 1974). The compensating procedure begins with subtracting ions introduced via precipitation. $\mathrm{Na}^{+}$was used for compensation of $\mathrm{Cl}^{-1}$. Nitrate ions were compensated mainly by $\mathrm{Ca}^{2+}$ and $\mathrm{Mg}^{2+}$. Compensating amounts were distributed according to the share of the elements in lysimetric water. The $\mathrm{SO}_{4}{ }^{2-}$ concentration was compensated by the same cations and the amounts used for compensation were determined by 
T a b l e 2. Chemical composition of lysimetric water $\left(\mathrm{mg} \mathrm{l}^{-1}\right)$ under $0-50$ and 0-100 $\mathrm{cm}^{-1}$ soil layer for the period of $1999-2008$

\begin{tabular}{|c|c|c|c|c|c|c|}
\hline \multirow{3}{*}{$\begin{array}{l}\text { Chemical } \\
\text { composition } \\
\left(\mathrm{mg} \mathrm{l}^{-1}\right)\end{array}$} & \multicolumn{6}{|c|}{ Rates of fertilization } \\
\hline & \multicolumn{2}{|c|}{$\mathrm{B}_{1}$} & \multicolumn{2}{|c|}{$\mathrm{B}_{3}$} & \multicolumn{2}{|c|}{$\mathrm{B}_{5}$} \\
\hline & $0-50 \mathrm{~cm}$ & $0-100 \mathrm{~cm}$ & $0-50 \mathrm{~cm}$ & $0-100 \mathrm{~cm}$ & $0-50 \mathrm{~cm}$ & $0-100 \mathrm{~cm}$ \\
\hline $\mathrm{pH}$ & 7.85 & 7.6 & 7.4 & 7.3 & 7.65 & 7.7 \\
\hline $\mathrm{K}^{+}$ & 1.66 & 1.28 & 2.12 & 2.03 & 2.27 & 1.86 \\
\hline $\mathrm{Na}^{+}$ & 16.52 & 16.68 & 17.85 & 15.6 & 18.14 & 17.99 \\
\hline $\mathrm{Ca}^{2+}$ & 50.30 & 44.32 & 65.15 & 56.65 & 69.10 & 66.37 \\
\hline $\mathrm{Mg}^{2+}$ & 17.32 & 14.76 & 16.45 & 18.62 & 16.69 & 17.50 \\
\hline $\mathrm{NO}_{3}{ }^{-} \mathrm{N}$ & 6.16 & 6.73 & 31.01 & 33.74 & 22.40 & 26.22 \\
\hline $\mathrm{HCO}_{3}^{-}$ & 114.51 & 93.36 & 61.89 & 71.30 & 102.42 & 91.75 \\
\hline $\mathrm{Cl}^{-}$ & 19.64 & 18.94 & 20.79 & 20.91 & 25.53 & 24.51 \\
\hline
\end{tabular}

the ratio of these elements regarding $\mathrm{SO}_{4}^{2-}$. Calcium compensates phosphorus. After compensation of $\mathrm{H}_{2} \mathrm{PO}_{4}^{-}$, the remaining $\mathrm{Ca}^{2+}$ and $\mathrm{Mg}^{2+}$ were bound by $\mathrm{HCO}_{3}^{-}$. After full compensation of the compounds, the ratio of the residual concentrations of $\mathrm{SiO}_{2}: \mathrm{HCO}_{3}{ }^{-}$and $\sum\left(\mathrm{K}^{+}+\mathrm{Na}^{+}\right)$in the lysimetric water was determined and the chemical nature of the weathering process was defined.

\section{RESULTS AND DISCUSSION}

A continuous anthropogenic impact on the soil, especially when growing intensive crops, has a considerable influence on its quality and environmental functions. The liquid phase of the soil first accepts all anthropogenic impacts, accumulates residual effects, and stores the information of the quality and strength of the influence. It is known that the liquid phase of the soil reacts very quickly and accurately reflects anthropogenic loadings applied on it. According to some researchers (Atanassov, 1977), the ionic composition of the leachate reflects pedogenic weathering of the mineral fraction of the soil. In this context, water could be regarded as 'filtrates' of weathering. When comparing the values of the mineral composition of Fluvisol with the ionic composition of the lysimetric water obtained, it is possible to determine the impact of the anthropogenic loading on the direction of the processes of pedogenic weathering. For this purpose, the system of estimates offered by Garels and Mackenzie (1974) was used. Following this system of the $\mathrm{SiO}_{2}$ residue in the drainage flow, it is possible to determine the type of changes in the mineral part of the soil. It was found that $\mathrm{SiO}_{2}$, as part of sesquioxides and various ratios between them, can provide important information about the crystalline and amphoteric components of the soil clay fraction, which on the other hand, determines the weathering of clay minerals.
The main source of base cations is via processes of weathering of silicates and the input from precipitation and irrigation, and very small amounts are added via fertilizers as well. We used the methodology for lysimetric water analysis and the compensation procedure as a study tool to estimate the effect of agricultural practices on the weathering process. This does not mean that no transformation occurs in the reference system (Meisinger and Randall, 1991; Ranger and Turpault, 1999). In this particular study, the steady-state situation was defined with respect to longterm $\mathrm{N}$ sources and sinks within the different $\mathrm{N}$ treatments.

The genesis of the lysimetric water is established on the basis of the mineral and chemical composition of this soil (Atanassov, 1977; Stoichev, 1974). If we assume that lysimetric water does not contain carbonates, the source of $\mathrm{Ca}^{2+}, \mathrm{Mg}^{2+}, \mathrm{Na}^{+}$, and $\mathrm{K}^{+}$in the waters are silicate and alum silicates in the soil (Table 2). As a result of the reaction between the soil minerals, water, and $\mathrm{CO}_{2}$ in the lysimetric water, $\mathrm{SiO}_{2}$ and cations were released in the water. The presence of $\mathrm{SiO}_{2}$ in the lysimetric water comes from the decomposition of the silicates. Data on the mineral composition of the studied soil (Behar et al., 1988) show that $\mathrm{SiO}_{2}$ in the solution is mainly a product of feldspar decomposition. The sources of $\mathrm{NO}_{3}^{-}$and $\mathrm{SO}_{4}{ }^{2-}$ ions in the lysimetric water have biological origin (biochemical processes in the soil) or were introduced via rainfall and fertilization. An increase in $\mathrm{SO}_{4}{ }^{2-}$ as a result of mineral weathering cannot be expected in this soil. The other cations in the lysimetric water $\left(\mathrm{K}^{+}\right.$and $\left.\mathrm{Na}^{+}\right)$and $\mathrm{SiO}_{2}$ originate from the weathering of feldspars. If we assume that transformation of the feldspars to kaolinite occurs in accordance with the reaction:

$$
\begin{aligned}
2 \mathrm{NaAlSi}_{3} \mathrm{O}_{8}+2 \mathrm{CO}_{2}+3 \mathrm{H}_{2} \mathrm{O}= & \mathrm{Al}_{2} \mathrm{Si}_{2} \mathrm{O}_{5}(\mathrm{OH})_{4}+2 \mathrm{Na}^{+} \\
+ & 2 \mathrm{HCO}_{3}^{-}+4 \mathrm{SiO}_{2},
\end{aligned}
$$


T a b l e 3. Balance of the components in lysimetic waters for the period of 1999-2008

\begin{tabular}{|c|c|c|c|c|c|c|c|c|c|}
\hline \multirow[b]{2}{*}{ Ions } & \multicolumn{2}{|c|}{$\begin{array}{l}\text { Contents of the } \\
\text { components }\left(\text { meq } 1^{-1}\right)\end{array}$} & \multirow[b]{2}{*}{$\begin{array}{l}\text { Difference } \\
\quad(2-3)\end{array}$} & \multicolumn{6}{|c|}{ Anions + compensating cations $\left(\right.$ meq $\left.1^{-1}\right)$} \\
\hline & $\begin{array}{l}\text { lysimetric } \\
\text { waters }\end{array}$ & $\begin{array}{l}\text { precipita- } \\
\text { tions }\end{array}$ & & $\mathrm{Cl}^{-}$ & $\mathrm{NO}_{3}^{-}$ & $\mathrm{SO}_{4}^{2-}$ & $\mathrm{H}_{2} \mathrm{PO}_{4-}$ & $\mathrm{HCO}_{3}^{-}$ & $\begin{array}{c}\text { Ratios } \\
\mathrm{SiO}_{2}: \\
\mathrm{HCO}_{3}^{-}: \\
\sum(\mathrm{Na}+\mathrm{K})\end{array}$ \\
\hline $\mathrm{K}^{+}$ & 0.08 & 0.063 & 0.017 & 0.167 & 0.167 & 0.167 & 0.167 & 0.167 & 0.337 \\
\hline $\mathrm{Na}^{+}$ & 0.724 & 0.072 & 0.652 & 0.170 & 0.170 & 0.170 & 0.170 & 0.170 & \\
\hline $\mathrm{Ca}^{2+}$ & 2.865 & 0.351 & 2.514 & 2.514 & 1.084 & 0.846 & 0.776 & 0 & \\
\hline $\mathrm{Mg}^{2+}$ & 1.359 & 0.153 & 1.206 & 1.206 & 1.206 & 0.786 & 0.614 & 0 & \\
\hline $\mathrm{HCO}_{3}$ & 1.702 & 0.546 & 1.156 & 1.156 & 1.156 & 1.156 & 1.156 & 0.312 & 0.312 \\
\hline $\mathrm{NO}_{3}^{-}$ & 1.780 & 0.254 & 1.526 & 1.526 & 0 & 0 & 0 & 0 & \\
\hline $\mathrm{Cl}^{-}$ & 0.557 & 0.373 & 0.184 & 0 & 0 & 0 & 0 & 0 & \\
\hline $\mathrm{SO}_{4}^{2-}$ & 0.928 & 0.467 & 0.461 & 0.461 & 0.461 & 0.461 & 0 & 0 & \\
\hline $\mathrm{H}_{2} \mathrm{PO}_{4-}$ & 0.070 & 0.010 & 0.600 & 0.060 & 0.060 & 0.600 & 0 & 0 & \\
\hline $\mathrm{SiO}_{2}$ & 0.417 & 0.054 & 0.363 & 0.363 & 0.363 & 0.363 & 0.363 & 0.363 & 0.363 \\
\hline Total amount & 10.412 & 2.343 & 12.755 & - & - & - & - & - & \\
\hline $\begin{array}{l}\text { Compensated } \\
\text { quantities }\end{array}$ & - & - & - & 0.184 & 1.526 & 0.461 & 0.060 & 0.844 & \\
\hline
\end{tabular}

for each $\mathrm{HCO}_{3}^{-}$two moles of $\mathrm{SiO}_{2}$ were formed, which was a very big amount to be compensated by the other ions in the lysimetric water. Otherwise, if the weathering of feldspars leads to formation of three-layer clay minerals (like montmorillonite) in accordance with the reaction:

$$
\begin{gathered}
2 \mathrm{NaAlSi}_{3} \mathrm{O}_{8}+2 \mathrm{CO}_{2}+2 \mathrm{H}_{2} \mathrm{O}=\mathrm{Al}_{2} \mathrm{Si}_{4} \mathrm{O}_{10}(\mathrm{OH})_{2}+2 \mathrm{Na}^{+}+ \\
2 \mathrm{HCO}_{3}^{-}+2 \mathrm{SiO}_{2},
\end{gathered}
$$

the ratio $\mathrm{SiO}_{2}: \mathrm{HCO}_{3}{ }^{-}: \sum\left(\mathrm{K}^{+}+\mathrm{Na}^{+}\right)=1: 1: 1$ is in full agreement with the compensated equivalents in the lysimetric water (Table 3) $\mathrm{SiO}_{2}: \mathrm{HCO}_{3}^{-}: \sum\left(\mathrm{K}^{+}+\mathrm{Na}^{+}\right)=0.363: 0.312$ : 0.337 . This suggests that the weathering of feldspars leads to the formation of three layer clay minerals (montmorillonite) (Atanassov, 1977).

The potassium content varies slightly for the all study periods (2009-2011) 0.90-5.87 $\mathrm{mg} \mathrm{l}^{-1}$. It was observed that the potassium content in lysimetric water was not substantially influenced by the fertilizer rates. The sodium content reaches the values of $23.44 \mathrm{mg} \mathrm{l}^{-1}\left(\mathrm{~B}_{5}-\mathrm{N}_{100} \mathrm{P}_{75}\right)$ in 2009 for 0-50 $\mathrm{cm}$ and 0-100 $\mathrm{cm}$ soil layer (Fig. 1a). The lowest values were observed in $2010-8.87 \mathrm{mg} \mathrm{l}^{-1}$ (Fig. 1b). The results show that in the lysimetric water, the cations of calcium dominate, which are indicative of Alluvial Meadow soil. When maize grew in 2010 , the $\mathrm{Ca}^{2+}$ content reached the highest values of $103 \mathrm{mg} \mathrm{l}^{-1}$ (Fig. 1c). We established that the $\mathrm{Mg}^{2+}$ behaviour fully corresponds to that of calcium. The experimental data show that the nitrate nitrogen content varied in a very wide range from 3.28 to $73.7 \mathrm{mg}$ $1^{-1}$ in 2009 (Fig. 1a). The greatest nitrogen concentration in lysimetric water was observed under variants $\left(\mathrm{B}_{3}-\mathrm{N}_{200} \mathrm{P}_{150}\right)$ for all the study periods. The study results show that the hydrocarbonate content ranged from 69.6 to $208 \mathrm{mg} \mathrm{l}^{-1}$.

It was found that the chemical composition of lysimetric water in the period of 2009-2011 was characterised by the same ratio of $\mathrm{SiO}_{2}: \mathrm{HCO}_{3}^{-}: \sum\left(\mathrm{K}^{+}+\mathrm{Na}^{+}\right)=0.363: 0.307$ : $0.319=1: 1: 1$.

The amount of nutrients leached out of the top onemeter soil profile (Table 4) was derived from the volume and element concentration of lysimetric water. The average amount of water leached out below $1 \mathrm{~m}$ ranged between 5 and $13 \%$ of the incoming water. Almost the whole amount of $\mathrm{N}$ leached was in the nitrate form. In all cases, fertilization had led to increasing $\mathrm{N}$ losses. During the study period of 2009-2011, the amount of $\mathrm{N}$ leached out from the control site was 10-20 times lower in comparison with fertilized treatments $B_{5}$ and $B_{3}$. The variation in nitrate 


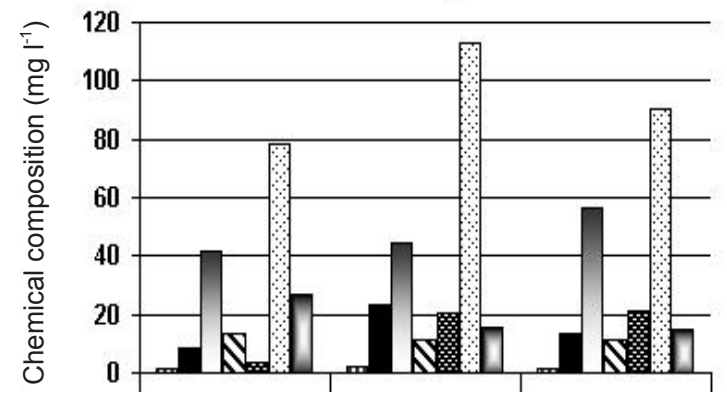

$\mathrm{b}$

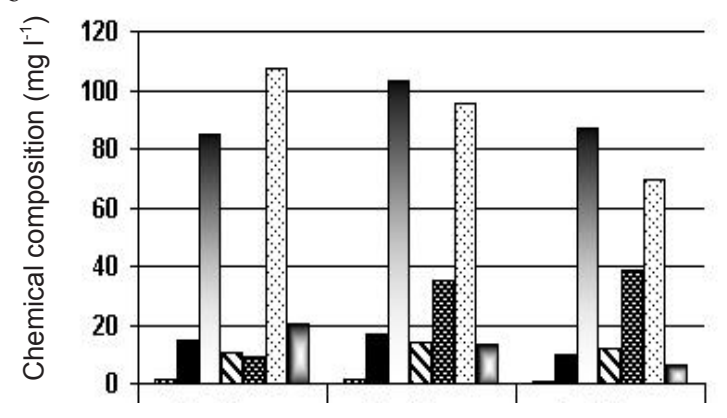

c

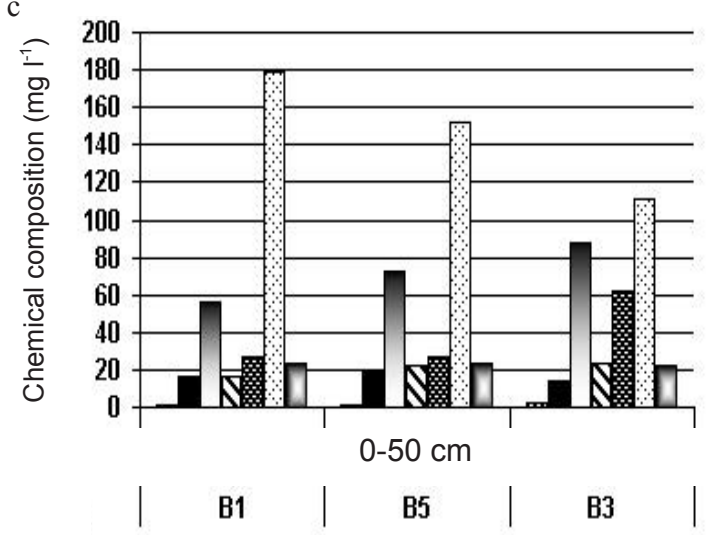

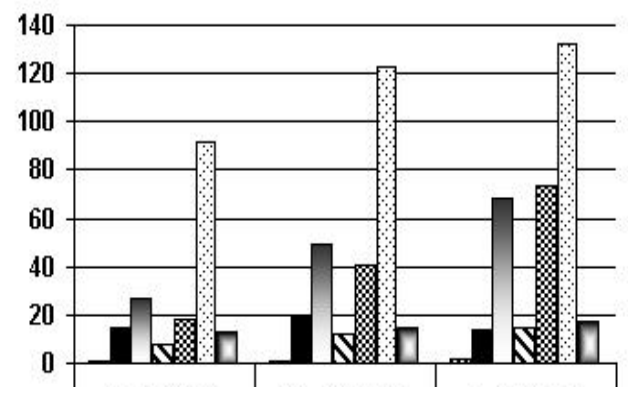
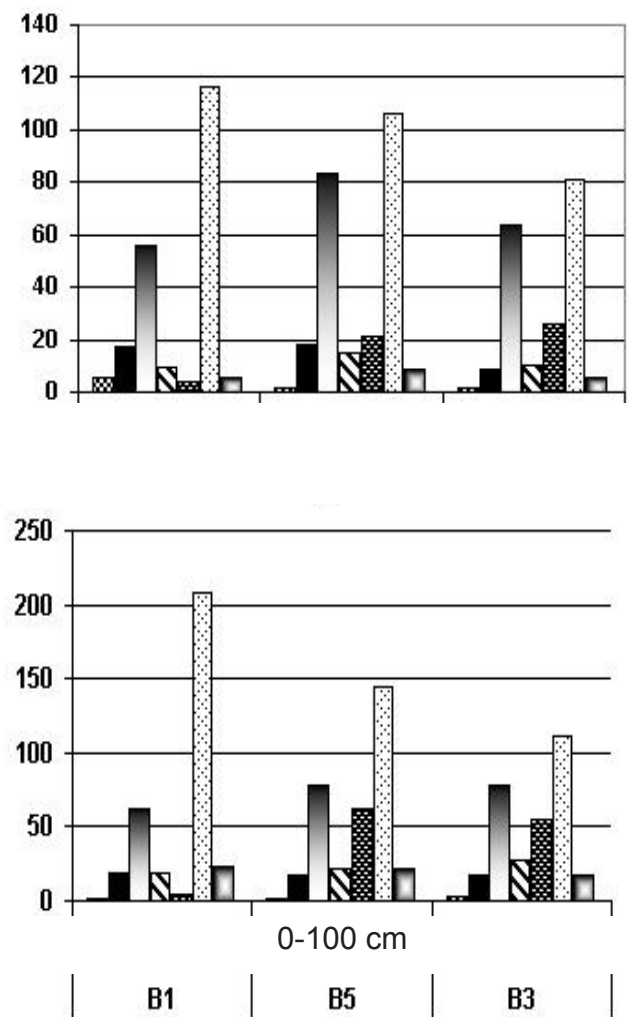

Fig. 1. Chemical composition of lysimetric waters under 0-50 and 0-100 cm soil layers in: $\mathrm{a}-2009, \mathrm{~b}-2010, \mathrm{c}-2011$.

leaching strongly depended on the precipitation and irrigation volume. The lowest $\mathrm{N}$ losses were registered in 2009 in treatment $\mathrm{B}$ with $\mathrm{N}$ leaching $0.2 \mathrm{~kg} \mathrm{ha}^{-1}$. The highest $\mathrm{N}$ losses were in the range from 36 and $25-26 \mathrm{~kg} \mathrm{ha}^{-1}$ in 2010 and 2011 (Table 4). Expressed in mass, the leaching of $\mathrm{Ca}^{2+}$ was the highest. The annual average losses of $\mathrm{Ca}^{2+}$ ranged from 7.4 to $80.0 \mathrm{~kg} \mathrm{ha}^{-1}$ depending on the $\mathrm{N}$ fertilizer rates. A very good correlation was found between the $\mathrm{N}$ rates and $\mathrm{Ca}^{2+}$ losses. Calcium leaching increased with the increasing $\mathrm{N}$ leaching rates. The same trend was observed in $\mathrm{Mg}^{2+}$ leaching but the absolute values were lower. Leaching of $\mathrm{K}^{+}$and $\mathrm{Na}^{+}$was not significantly affected by the fertilizer inputs. The migration of hydrocarbonates decreased with the increasing fertilizer rates, especially in 2011.

\section{CONCLUSIONS}

1. The studied Fluvisol has very high spatial heterogeneity due to the soil formation process and distribution of alluvial sediments through the soil profile and hence very high variation between leachate volumes was observed. 
T a b l e 4. Migration of chemical elements $\left(\mathrm{kg} \mathrm{ha}^{-1}\right)$ with lysimetric water through 0-100 $\mathrm{cm}$ soil layer for the period of 2009-2011 (maize)

\begin{tabular}{|c|c|c|c|c|c|c|c|c|c|c|c|}
\hline \multirow{2}{*}{ Treatment } & \multirow{2}{*}{$\begin{array}{c}\text { Depth } \\
(\mathrm{cm})\end{array}$} & \multirow{2}{*}{$\mathrm{pH}$} & \multicolumn{9}{|c|}{ Migration of chemical elements $\left(\mathrm{kg} \mathrm{ha}^{-1}\right)$} \\
\hline & & & $\mathrm{K}^{+}$ & $\mathrm{Na}^{+}$ & $\mathrm{Ca}^{2+}$ & $\mathrm{Mg}^{2+}$ & $\mathrm{N}-\mathrm{NO}_{3}^{-}$ & $\mathrm{HCO}_{3}^{-}$ & $\mathrm{Cl}^{-}$ & $\mathrm{SiO}_{2}$ & $\mathrm{SO}_{4}^{2-}$ \\
\hline \multicolumn{12}{|c|}{2009} \\
\hline \multirow{2}{*}{$\mathrm{B}_{1}$} & $0-50$ & 7.90 & 0.5 & 5.7 & 8.9 & 2.7 & 0.2 & 27.1 & 5.8 & - & - \\
\hline & $0-100$ & 7.90 & 0.3 & 4.8 & 8.7 & 2.5 & 5.9 & 30.1 & 4.2 & 3.3 & 12.1 \\
\hline \multirow{2}{*}{$\mathrm{B}_{3}$} & $0-50$ & 7.65 & 0.6 & 4.5 & 19.1 & 3.9 & 7.3 & 30.6 & 5.0 & 4.4 & 32.6 \\
\hline & $0-100$ & 7.75 & 0.5 & 4.9 & 23.6 & 5.2 & 25.5 & 44.8 & 6.1 & 3.6 & 35.6 \\
\hline \multirow{2}{*}{$\mathrm{B}_{5}$} & $0-50$ & 7.85 & 0.3 & 3.9 & 7.4 & 1.9 & 3.4 & 18.8 & 2.5 & 1.9 & 16.5 \\
\hline & $0-100$ & 7.65 & 0.5 & 8.8 & 22.7 & 5.4 & 18.9 & 56.5 & 6.6 & 6.2 & 54.5 \\
\hline \multicolumn{12}{|c|}{2010} \\
\hline \multirow{2}{*}{$\mathrm{B}_{1}$} & $0-50$ & 8.00 & 3.2 & 3.8 & 21.8 & 2.8 & 2.3 & 27.6 & 5.2 & - & 16.9 \\
\hline & $0-100$ & 8.15 & 2.5 & 7.2 & 22.8 & 3.9 & 1.7 & 47.7 & 2.2 & 4.0 & 27.3 \\
\hline \multirow{2}{*}{$\mathrm{B}_{3}$} & $0-50$ & 8.00 & 0.9 & 8.8 & 80.8 & 9.0 & 36.0 & 64.7 & 5.8 & 3.0 & 39.8 \\
\hline & $0-100$ & 7.90 & 1.0 & 10.0 & 52.4 & 8.2 & 21.4 & 66.9 & 4.3 & 8.2 & 45.5 \\
\hline \multirow{2}{*}{$\mathrm{B}_{5}$} & $0-50$ & 8.00 & 1.0 & 1.0 & 78.7 & 0.9 & 26.7 & 72.8 & 10.1 & 3.1 & 77.8 \\
\hline & $0-100$ & 8.00 & 1.3 & 14.8 & 69.5 & 2.2 & 17.9 & 88.8 & 7.3 & 8.0 & 82.6 \\
\hline \multicolumn{12}{|c|}{2011} \\
\hline \multirow{2}{*}{ B1 } & $0-50$ & 7.80 & 0.7 & 8.1 & 27.0 & 8.1 & 12.9 & 85.8 & 11.0 & 11.9 & 47.3 \\
\hline & $0-100$ & 8.15 & 0.7 & 6.5 & 21.7 & 6.5 & 1.3 & 72.1 & 8.1 & 7.6 & 42.2 \\
\hline \multirow{2}{*}{ B3 } & $0-50$ & 7.30 & 0.8 & 5.7 & 36.8 & 9.7 & 26.0 & 46.1 & 9.3 & 0.4 & 53.5 \\
\hline & $0-100$ & 7.40 & 1.3 & 8.3 & 36.7 & 2.7 & 25.8 & 52.8 & 8.2 & 8.0 & 42.4 \\
\hline \multirow{2}{*}{ B5 } & $0-50$ & 8.00 & 0.5 & 7.4 & 28.9 & 8.6 & 10.6 & 68.4 & 9.4 & 9.1 & 46.9 \\
\hline & $0-100$ & 7.80 & 0.2 & 3.6 & 16.1 & 4.4 & 12.7 & 29.6 & 4.4 & 4.5 & 23.0 \\
\hline
\end{tabular}

2. The type of land-use and different fertilizer rates are Atanassov I., Qawasmi W.Al., and Stoichev D., 1985. Effect of among factors that influenced element leaching and losses.

3. By this compensating procedure, it was established that agricultural practices had influenced only the intensity of weathering but did not lead to significant changes in the geochemical nature of the process and weathering rates.

Conflict of interest: The Authors do not declare conflict of interest.

\section{REFERENCES}

Arinushkina E., 1970. Guidelines in Chemical Soil Analysis. Izd. MGU, Moskow, Russia.

Atanassov I., 1977. Weathering and evolution of the mineral part of Bulgarian soils. Ph.D. Sc. Dissertation, University of Agriculture, Sofia, Bulgaria. frertilizer application on the migration of chemical elements with lyzimetric waters, Soil Sci., Agrochemistry Plant Protection, 20(4), 48-55.

Behar A., Hubenov G., Dancheva M., and Philipov Ch., 1988. Mineral content of soils along the tributaries of the Maritsa River, Soil Sci. Agrochem., 23(4), 3-10.

Chadwick O.A. and Chorover J., 2001. The chemistry of pedogenic thresholds, Geoderma, 100, 321-353.

FAO, 1998. World Reference Base for Soil Resources. Rome: Food and Agriculture Organization of the United Nations

Garrels P. and Makkensi F., 1974. Evolution of silicate minerals. Izd. Mir, Moscow, Russia.

Koynov V., 1987. Correlation between soils in Bulgaria and the main soils, determined by the world soil classification system, Soil Sci. Agrochem. Plant Protect., 22(5), 5-13.

Levichanska E., 1991. Climate of Bulgaria. Publiching House of Bulgarian Academy of Science, Sofia, Bulgaria. 
Meisinger J.J. and Randall G.W., 1991. Estimating nitrogen budgets for soil-crop systems. In: Managing Nitrogen for Groundwater Quality and Farm Profitability (Eds R.F. Follett, D.R. Keeney, R.M. Cruse). Soil Science Society of America Inc., Medison WI, USA.

Meissner R., Prasad M.N., Du Laing V., and Rinklebe G.J., 2010. Lysimeter application for measuring the water and solute fluxes with high precision. Curr. Sci., 99, 601-607.

Page A., Miller R.H., and Keeney D.R., 1982. Methods of Soil Analysis. Part 2. Chemical and Microbiological Properties, (Eds Page, A., Miller, R.H., Keeney, D.R.), ASA and SSSA, Madison, Wisconsin, USA.

Ranger J. and Turpault M., 1999. Input-output budgets as a diagnostic tool for sustainable forest management. Forest Ecol Manag., 122, 139-154.

Stoichev D., 1974. A device to obtain lyzimetric water. Soil Science Agrochemistry, 9, 13-18.

Stoichev D., 1997. Some ecological aspects of the anthropogenic loading on the soils. Ph.D. Sc. Dissertation, Nikola Poushkarov" Institute of Soil Science and Agroecology, Sofia, Bulgaria.
Stoichev D., Stoicheva D., Angelov G., and Dimitrova K., 1996. Effect of long-term fertilization on nitrogen leaching. In: Proc.e 8th Nitrogen Workshop "Progress in Nitrogen Cycling Studies" (Eds Van Cleemput et al.). Kluwer Academic Publishers, The Netherlands.

Taylor A.B. and Velbel M.A., 1991. Geochemical mass balance and weathering rates in forested watersheds of the Southern Blue Ridge II. Effect of botanical uptake terms. Geoderma, 51, 29-50.

White A. and Blum A., 1995. Effects of climate on chemical weathering in watershed. Geochimica et Cosmochimica Acta, 59, 1729-1747.

Yakubu M. and Ojanuga A.G., 2013. Pedogenesis, weathering status and mineralogy of the soils on ironstone plateaux (laterites), Sokoto Nigeria. Bayero J. Pure Applied Sci., 6(2), 93-100.

Zhao C., Hu C., Huang W., Sun X., Tani Q., and Di H., 2010. A lysimeter study of nitrate leaching and optimum nitrogen application rates for intensively irrigated vegetable production system in Central China. J. Soil Sediments, 10, 9-17. 